\title{
INFLUENCE OF SEEDLING AGE ON CUCUMBER (Cucumis sativus L.) PRODUCTION
}

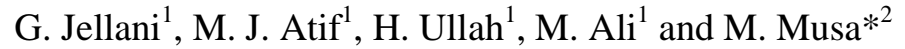 \\ Directorate of Vegetable, National Agricultural Research Center, Islamabad, Pakistan
}

\begin{abstract}
Cucumber crop was evaluated for the influence of seedling age on its production during two consecutive years of 2011 and 2012 on experimental area of National Agricultural Research Center (NARC), Islamabad, Pakistan. Nursery of cucumber was raised in polythene tubes under protected structures (walk-in tunnels). Seedling transplantation of three different ages viz., 30, 45 and 60 days were compared with direct seeding in the open field. Seedling transplantation produced fruits earlier (22 days), increased availability period (41 days) as compared to direct seeded crop. Transplantation of 45 and 60 days old seedlings produced higher fruits yield of cucumber with higher gross return and gross margin. The results revealed that transplantation of 45 to 60 days old seedlings was suitable for achieving fruits earlier and profitable cucumber production technology.
\end{abstract}

Keywords: Cucurbits, cucumber, early crop, seedling age and gross margin

\section{INTRODUCTION}

Cucumber is cultivated on an area of 3499 hectares with an annual production of 449947 tonnes in Pakistan (GOP, 2013-14). Cucumber productivity is highly dependent on different factors such as light, temperature, $\mathrm{CO}_{2}$, humidity, water supply, fertilization, cultivation methods and varieties etc (Juknys et al., 2011). Among those, temperature plays a significant role in cucumber production. Cucumber seedling is easily injured by frost; consequently, direct seeding in the field is delayed until the danger of frost is ended (Hussain et al., 1989). Cucumber seedlings may be successfully raised under plastic tunnels during cooler months and healthy seedlings can be transplanted at most favourable age. Seedling age greatly influences the vegetative development of the crop, vegetative mass, biochemical composition, output of standard transplants, plant growth after transplantation and

\footnotetext{
* Corresponding author email: mum96@hotmail.com

${ }^{1}$ Directorate of Vegetable, National Agricultural Research Center, Islamabad, Pakistan

${ }^{2}$ Barani Agricultural Research Institute, Chakwal, Pakistan
} 
resistance to critical conditions (Henare and Ravanloo, 2008). Seedlings of an older age are more tolerant to stress and produce fruits earlier, while young transplants are less tolerant (Vavrina, 1998). Seedlings transplanted at their older age develop reproductive phase quicker than vegetative phase (Orzolek, 2004). To encourage quick plant growth and early harvest, the technique of transplanting cucumber seedlings may be applied. Optimum seedling age for better plant establishment could enhance productivity of cucumber crop (Handley and Hutton, 2003). The effect of seedling age on yield is an issue often introduced by the growers to maximize production potential (Holcomb, 1994). Optimum seedlings age determine early production as well as higher yield of crop which favours the farmers to get higher market price. Therefore, the aim of present study was to observe the influence of seedling age on cucumber production which would be economical as well as beneficial for farmers.

\section{MATERIALS AND METHODS}

The experiment was carried out at the experimental field of National Agricultural Research Centre (NARC), Islamabad, Pakistan during two consecutive years of 2011 and 2012. The experimental site was located at $73.08^{0}$ E Longitude, $33.42^{0} \mathrm{~N}$ Latitude and $683 \mathrm{msl}$. Soil texture was sandy loam with $\mathrm{pH} 7.8$. Nursery of cucumber (Variety: Sialkot selection) was raised in plastic tubes under plastic tunnel in a medium comprising Farm Yard Manure (FYM), sand and soil with a proportion of 1:1:1, respectively. Four treatments viz., $\mathrm{T}_{0}$ : Traditional direct sowing practice, $\mathrm{T}_{1}$ : 30 days old seedlings, $\mathrm{T}_{2}: 45$ days old seedlings, $\mathrm{T}_{3}: 60$ days old seedlings were compared under field condition. The experiment was laid out in randomized complete block design with three replications. FYM @ $7 \mathrm{t} \mathrm{ha}^{-1}$ was incorporated in to soil as organic amendment at the time of land preparation one month before transplantation. Seedlings of different ages according to treatments were transplanted on 03 March, 2011 and 05 March, 2012 maintaining row to row and plant to plant distance of $1.5 \mathrm{~m}$ and $50 \mathrm{~cm}$, respectively. Direct seeding was done on the same day. Data were collected on days to first picking, availability period, survival percentage, fruits weight per plant and fruit yield $\left(\mathrm{t} \mathrm{ha}^{-1}\right)$. Collected data were analyzed using statistics 8.1 software package. Means of different parameters were ranked according to Least Significant Difference (LSD) Test (Steel et al., 1997). Gross return and gross margin were also calculated.

\section{RESULTS AND DISCUSSION}

The values of all the parameters under study showed similar trend indicated similar performance of treatments in both the years. Two years mean of each trait was computed and discussed here. 


\section{Days to first picking, availability period and survival percentage}

Significant differences were observed among different seedling age treatments for first picking time, availability period of the produce and survival percentage of the plants. Two years mean values indicated that seedlings irrespective of their age produced fruits earlier compared to direct seeded crop. First fruit was harvested about 22 days earlier (Table 2). Singh et al. (2010) also proved the technique of raising seedlings for early harvesting of cucurbit in India. Availability period was about 41 days in 30 to 60 days old seedling, whereas it was 21 days in direct seeded crop. The results revealed that availability period was 20 days more in 30 to 60 days old seedlings than in direct seeded crop. Survival percentage was recorded $100 \%$ in treatments of seedlings, whereas it was $75 \%$ in direct seeded crop (Table 2). Minimum survival rate in direct seeded crop might be due to poor root growth. Poor survival of cucumber crop in direct sowing method was also recorded by Handley and Hutton (2003). However, all seedling treatments proved statistically similar for all above described traits. These results are also supported by Hasandokht and Nosrati (2010).

\section{Fruit weight per plant and fruit yield}

Fruits weight per plant differed significantly among different seedling age treatments (Table 3). Averaged over years, maximum fruits weight per plant (884.31 g) was recorded from crops raised through 60 days old seedlings, which was statistically similar to that of 45 days old seedlings $(859.17 \mathrm{~g}$ ) but significantly higher than other treatments.. Fruit yield was also varied significantly among different treatments. In case of fruit yield, similar trend was observed to that of fruit weight per plant. Fruit yield obtained from 60 days old seedlings was the highest $\left(17.69 \mathrm{t} \mathrm{ha}^{-1}\right)$, which was at par with that of 45 days old seedlings $\left(77.19 \mathrm{t} \mathrm{ha}^{-1}\right)$, while both treatments produced significantly higher fruit yield as compared to 30 days old seedling and direct seeded crop. Different scientists (Hasandokht and Nosrati, 2010; Orzolek, 2004) also reported that vegetables cultivated from older seedlings produced higher yields. These results are also in line with the findings of Choudhari et al. (2002). However, according to Liptay (1988), the yields from the seedlings of different ages are similar, in spite of the fewer yield from younger seedlings of cucumber. Minimum fruits yield $\left(11.40 \mathrm{t} \mathrm{ha}^{-1}\right)$ was recorded from direct seeded crop. NeSmith (1994) also reported lower fruit yield in direct seeded zucchini squash than four weeks old transplants. Increase in fruit yield at 60 days old seedlings over direct seeding was maximum (55.18\%) which was statistically at par with 45 days old seedlings $(50.79 \%)$. On the contrary, fruit yield increment was minimum $(35.53 \%)$ at 30 days old seedlings over direct seeding (Figure 2).

\section{Gross margin and gross return}

Averaged over years, gross margin and gross return also behaved similarly as fruit yield. The highest gross margin (US\$ $989.5 \mathrm{ha}^{-1}$ ) was found from 60 days old seedlings and it was statistically similar to 45 days old cucumber seedlings (US\$ 
936.8), while the lowest gross margin of US\$ $412.3 \mathrm{ha}^{-1}$ was recorded from direct seeded crop (Figure 1). This result further revealed (Figure 2) that the increment of gross margin in 60 days old seedlings was maximum (140\%) over direct seeded crop, which was statistically similar to 45 days old seedlings (127.21\%). Increase in gross margin with 30 days old seedlings over direct seeded crop was minimum (85.06\%). Likewise, gross return was 41.34 to $44.33 \%$ higher in 45 to 60 days old cucumber seedlings over direct seeded crop. Higher gross return and gross margin in older cucumber seedlings were attributed to the higher fruit yield owing to have more availability period and higher survival rate (Figure 2).

\section{CONCLUSION}

The two-year results revealed that seedling transplantation was superior to traditional direct seeded cucumber. Seedlings of 45-60 days old produced higher fruit yield, gross return and gross margin. Farmers might be suggested to transplant 45-60 days old seedlings for profitable cucumber production.

\section{REFERENCES}

Choudhari, S. M., More, T. A. and Tazuke, A. 2002. Fertigation, fertilizer and spacing requirement of tropical gynoecious cucumber hybrids. Acta Horticulture, 588: 233-240

GOP. 2013-14. Fruits, Vegetables and Condiments Statistics of Pakistan. Ministry of National Food Security and Research (Economic Wing), Islamabad.

Handley, D. and Hutton, M. 2003. Effect of seeding date, transplant size and container on growth and yield of pickling cucumbers. Journal of the American Society for Horticultural Science, 38: 672

Hasandokht, M. R. and Nosrati, S. Z. 2010. Effect of transplant age and fruit pruning on earliness and total yield of greenhouse cucumber (Cucumis sativus L. cv. Sultan). Plant Ecophysiology, 2: 21-25

Henare, M., and Ravanloo, A. 2008. Effect of transplanting stage and planting depth of seedling on growth and yield of tomato. Book of abstracts. IV Balkan Symposium on Vegetables and Potatoes. Plovdiv, 96

Holcomb, E.J. (ed.). 1994. Bedding Plants IV. Ball Publishing, Batavia, Ill.

Hussain, S. ASZI., Khokar, K. M. and Farooq, M. 1989. Modern production practices of cucumber. Progressive Farming, 9: 21-3

Juknys, R., Duchovskis, P., Sliesaravicius, A., Slepetys, J., Januskaitiene, I., Brazaityte, A., Ramaskeviciene, A., Lazauskas, S., Dedeliene, K., Sakalauskaite, J., Juozaityte, R., Kadziuliene, Z., and Diksaityte, A. 2011. Response of different agricultural plants to elevated $\mathrm{CO}_{2}$ and air temperature. Zemdirbyste-Agriculture, 97 (2): 89-98

Liptay, A. 1988. Field survival and establishment of tomato transplants of various age and size. Acta Horticulture, 220: 203-210

NeSmith, D. S. 1993 or 1994. Transplant age has little influence on yield of muskmelon (Cucumis melo L.). Hort. Sci. 29(8): 916. 
Orzolek, M. 2004. Evaluating vegetable transplants. Vegetable, small fruit and specialty crops. Virginia Cooperative Extension, 3(3): 9

Singh, B., Tomar, B. S. and Hasan, M. 2010. Plug tray nursery raising technology for off season cucurbits cultivation. Acta Horticulture, (ISHS), 871: 279-282

Steel, R. G. D., Torrie, J. H. and Boston, M. A. 1997. Principles and Procedures of Statistics. $2^{\text {nd }}$ Ed. McGraw Hill, New York. 636

Vavrina, C. S.1998. Transplant age in vegetable crops. Horticultural Technology, 8 (4): 550555. 
Table 1. Meteorological data during the study period of 2011 and 2012

\begin{tabular}{lcccc}
\hline $\begin{array}{c}\text { Period of } \\
\text { study }\end{array}$ & $\begin{array}{c}\text { Max Temp } \\
\left({ }^{\circ} \mathbf{C}\right)\end{array}$ & $\begin{array}{c}\text { Min Temp } \\
\left({ }^{\circ} \mathbf{C}\right)\end{array}$ & $\begin{array}{c}\text { Relative Humidity } \\
(\mathbf{\%})\end{array}$ & $\begin{array}{c}\text { Rainfall } \\
(\mathbf{m m})\end{array}$ \\
\hline January, 2011 & 17.3 & 1.8 & 71.3 & 8.32 \\
February, 2011 & 17.7 & 5.8 & 75.8 & 78.73 \\
March, 2011 & 25.8 & 10.2 & 63 & 53.19 \\
April, 2011 & 28.8 & 13.5 & 61 & 53.96 \\
May, 2011 & 38.1 & 20.4 & 45 & 17.29 \\
January, 2012 & 16.9 & 1.32 & 68.5 & 59.06 \\
February, 2012 & 17.4 & 3.24 & 70.1 & 44.12 \\
March, 2012 & 24.9 & 8.9 & 58.6 & 15.95 \\
April, 2012 & 29.9 & 15.0 & 54.7 & 40.93 \\
May, 2012 & 26.2 & 18.3 & 38.4 & 9.47 \\
\hline
\end{tabular}

Source: Metrological Section, Water Resources Research Institute (WRRI), NARC, Islamabad 
Table 2. Influence of seedlings age on days to $1^{\text {st }}$ picking, availability period and survival of cucumber

\begin{tabular}{|l|c|c|c|c|c|c|c|c|c|}
\hline \multirow{2}{*}{ Treatment } & \multicolumn{3}{|c|}{ Days to 1 } & \multicolumn{2}{c|}{ Availability Period (days) } & \multicolumn{2}{c|}{ Survival rate of plants (\%) } \\
\cline { 2 - 10 } & $\mathbf{2 0 1 1}$ & $\mathbf{2 0 1 2}$ & Mean & $\mathbf{2 0 1 1}$ & $\mathbf{2 0 1 2}$ & Mean & $\mathbf{2 0 1 1}$ & $\mathbf{2 0 1 2}$ & Mean \\
\hline Direct sowing & 63.00 & 64.25 & $63.63 \mathrm{a}$ & 21.25 & 22.25 & $21.75 \mathrm{~b}$ & 77.50 & 77.50 & $75.50 \mathrm{~b}$ \\
\hline $\begin{array}{l}\text { 30 days old } \\
\text { seedlings }\end{array}$ & 41.50 & 41.50 & $41.50 \mathrm{~b}$ & 40.25 & 41.25 & $40.75 \mathrm{a}$ & 100.00 & 100.0 & $100.00 \mathrm{a}$ \\
\hline $\begin{array}{l}\text { 45 days old } \\
\text { seedlings }\end{array}$ & 42.00 & 41.50 & $41.75 \mathrm{~b}$ & 40.75 & 40.50 & $40.62 \mathrm{a}$ & 100.00 & 100.0 & $100.00 \mathrm{a}$ \\
\hline $\begin{array}{l}\text { 60 days old } \\
\text { seedlings }\end{array}$ & 42.00 & 41.50 & $41.75 \mathrm{~b}$ & 41.25 & 41.25 & $41.25 \mathrm{a}$ & 100.00 & 100.0 & $100.00 \mathrm{a}$ \\
\hline Year means & 47.19 & 47.12 & & 35.88 & 36.31 & & 94.37 & 94.37 & \\
\hline & Treatment & Year & Interaction & Treatment & Year & Interaction & Treatment & Year & Interaction \\
\cline { 2 - 10 } & 1.44 & $* \mathrm{NS}$ & $* \mathrm{NS}$ & 0.93 & $* \mathrm{NS}$ & $* \mathrm{NS}$ & 2.58 & $* \mathrm{NS}$ & $* \mathrm{NS}$ \\
\hline
\end{tabular}

*NS: non-significant

Table 3. Influence of seedlings age on yield and gross return from cucumber

\begin{tabular}{|l|c|c|c|c|c|c|}
\hline \multirow{2}{*}{ Treatment } & \multicolumn{3}{c|}{ Yield plant $^{-1}$ (g) } & \multicolumn{3}{c|}{ Yield (t ha $\left.^{-\mathbf{1}}\right)$} \\
\cline { 2 - 7 } & $\mathbf{2 0 1 1}$ & $\mathbf{2 0 1 2}$ & Mean & $\mathbf{2 0 1 1}$ & $\mathbf{2 0 1 2}$ & Mean \\
\hline Direct sowing & 730.75 & 721.60 & $26.17 \mathrm{c}$ & 11.65 & 11.15 & $11.40 \mathrm{c}$ \\
\hline \multirow{2}{*}{30 days old seedlings } & 766.20 & 778.73 & $772.46 \mathrm{bc}$ & 15.32 & 15.58 & $15.45 \mathrm{~b}$ \\
\hline 45 days old seedlings & 910.03 & 808.31 & $859.17 \mathrm{ab}$ & 18.20 & 16.18 & $17.19 \mathrm{a}$ \\
\hline 60 days old seedlings & 947.88 & 820.75 & $884.31 \mathrm{a}$ & 18.95 & 16.42 & $17.69 \mathrm{a}$ \\
\hline Year means & 838.71 & 782.35 & & $16.03 \mathrm{a}$ & $14.83 \mathrm{~b}$ & \\
\hline \multirow{2}{*}{ LSD } & Treatment & Year & Interaction & Treatment & Year & Interaction \\
\cline { 2 - 7 } & 90.75 & $* N S$ & $* N S$ & 1.627 & 1.151 & $* N S$ \\
\hline
\end{tabular}

*NS: non-significant 


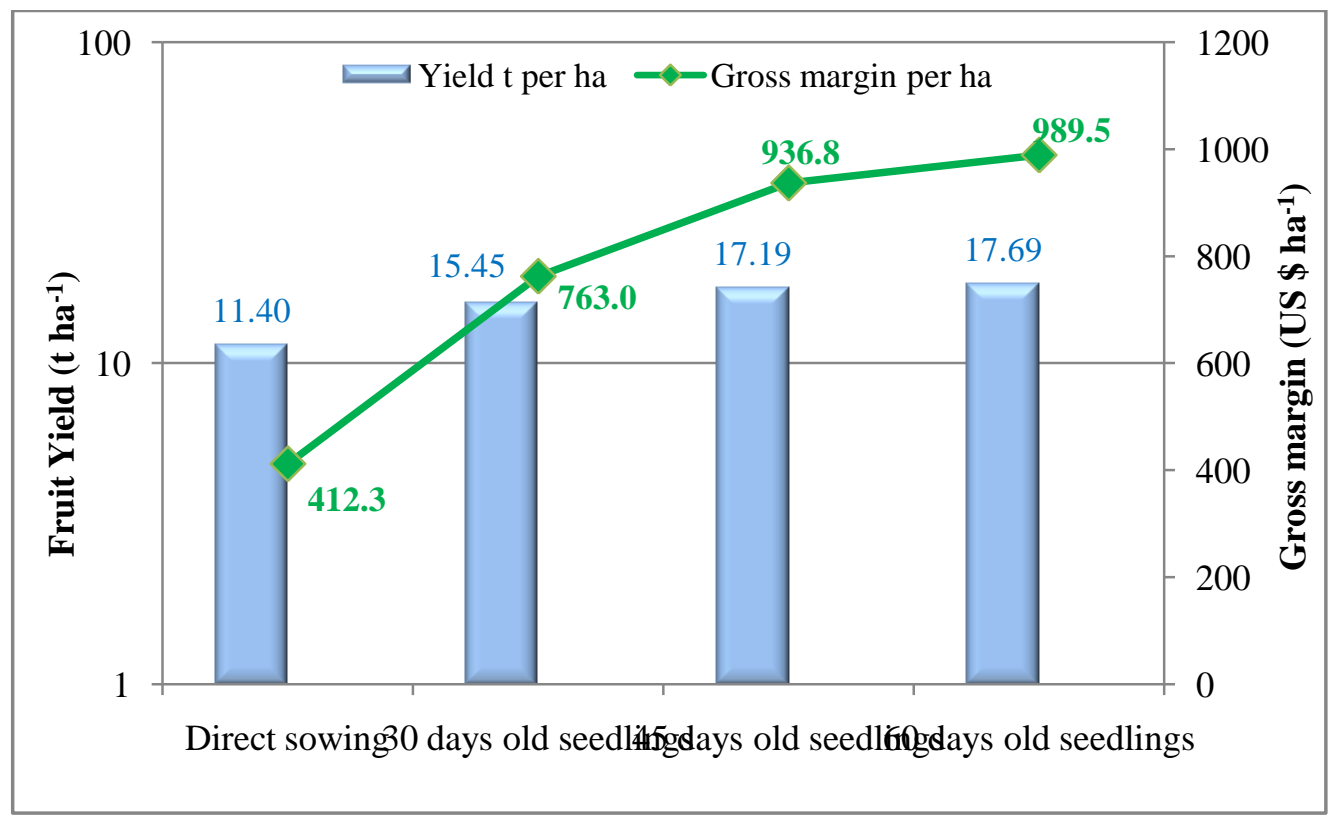

Figure 1. Effect of seedling age on fruit yield and attained grass margin from cucumber (2-year average)

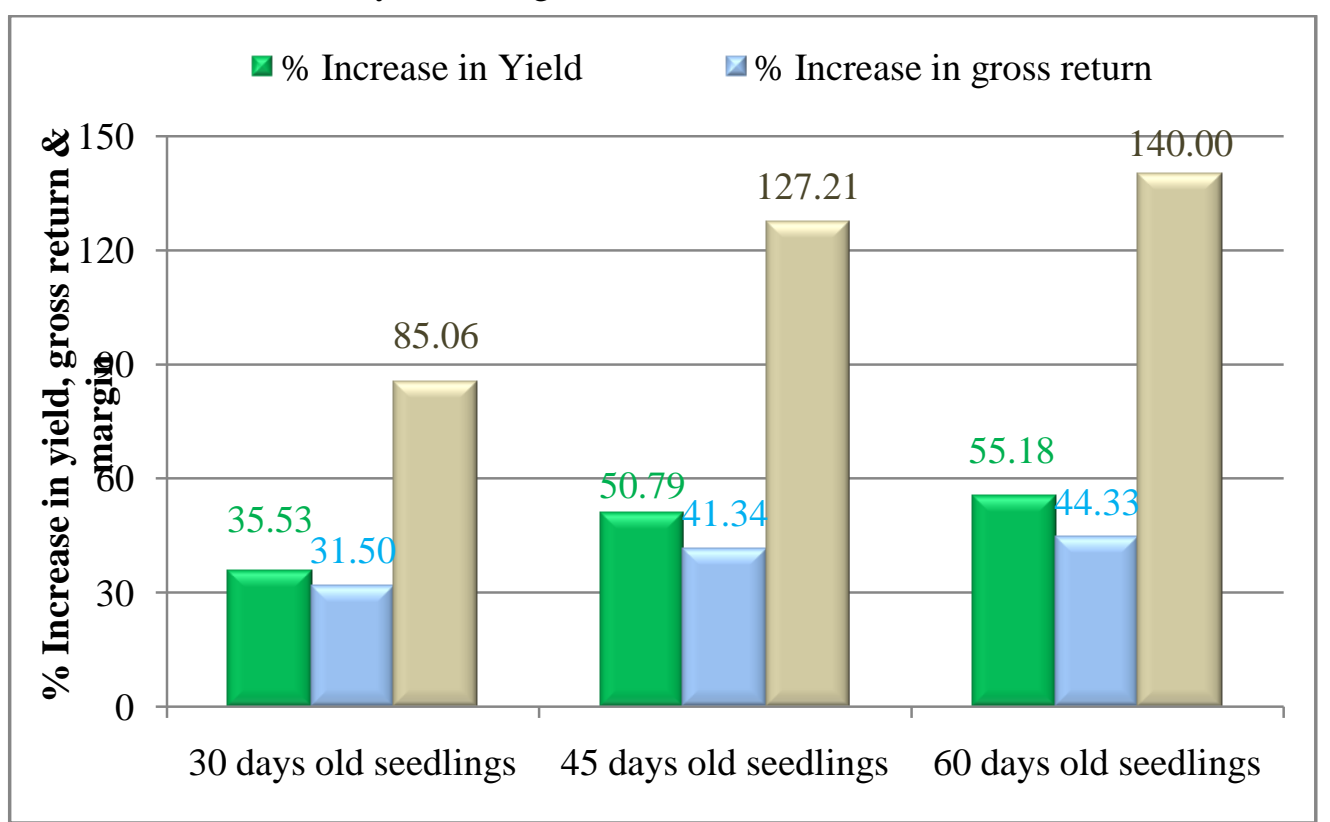

Figure 2. \% Increase in fruit yield, gross return and gross margin of cucumber from different aged seedlings over direct sowing (2-year average) 